Universal Decimal Classification (UDC) 616-008.1

\title{
FEATURES OF CARDIAC DISORDERS IN CHILDREN WITH CHRONIC RESPIRATORY DISEASES ASSOCIATED WITH AEROGENIC EXPOSURE TO CHEMICAL ENVIRONMENTAL FACTORS
}

\author{
O.A. Maklakova ${ }^{1,2}$, O.Yu. Ustinova ${ }^{1,2}$, E.S. Belyaeva ${ }^{1}$, A.A. Sherbakov ${ }^{1}$ \\ ${ }^{1}$ FBSI «Federal Scientific Center for Medical and Preventive Health Risk Management Technologies», 82 \\ Monastyrskaya St., Perm, 614045 Russian Federation \\ ${ }^{2}$ FBSEI HPE "Perm State National Research University”, 15 Bukireva St., Perm, , 614990, Russian Federation
}

\begin{abstract}
The study has involved 43 children living in areas with poor air quality as per sanitary and hygienic indicators. Children suffering from bronchial asthma and recurrent bronchitis associated with exposure to anthropogenic chemicals (suspended solids, aromatic and oxygenated hydrocarbons, formaldehyde) have shown evidence of peripheral obstruction and functional cardiac disorders during remission in $24 \%$ of cases. As children with chronic respiratory diseases are exposed to adverse effects of anthropogenic chemical factors they suffer from autonomic dysfunctions of cardiac type, which are usually associated with sinus bradytachycardia, eytonic and/or sympathicotonic baseline autonomic tone, hypersympathicotonic / astimpathicotonic autonomic reactivity. $17.9 \%$ children have transient diastolic dysfunction of right ventricle and increased systolic pressure in pulmonary artery.
\end{abstract}

Key words: children, cardiorespiratory disorders, bronchial asthma, recurrent bronchitis, diastolic dysfunction.

Respiratory diseases persistently have the biggest share in the overall structure of children morbidity. However, over the last five years we have seen a slight decrease in morbidity levels of chronic bronchitis, chronic obstructive diseases, and bronchial asthma from 1521.2 to 1325.6 cases per 100 thousand children $[5,7,8]$. According to official statistics, level of bronchial asthma and chronic bronchitis morbidity was above average in 30 regions of the Russian Federation. Air in big cities is polluted with mixture of chemicals emitted by industries and public transport; such mixture usually consists of suspended solids, carbon monoxide, nitrogen dioxide, aromatic hydrocarbons, formaldehyde, and other pollutants [1, 4, 8]. In spite of the fact that we have been observing some fall in the pollution levels, we can still see that in 2014 the situation with air pollution was far from being normal in Uralsky, Dalnevostochniy and Sibirskiy federal districts [8].

A lot of researchers have studied a variety of cardiovascular disorders which are characteristic for children suffering from bronchopulmonary diseases in acute condition [2, 3, 5, 6, 10, 11]. It is proved that chronic inhalant combined effect of suspended solids, benzene, toluene, phenol and formaldehyde leads to evolvement of local chronic inflammatory process in mucous tunic of respiratory tract together with mucociliary clearance disorder, dystrophic processes development and bronchial hyperreactivity $[1,3,4,13,14,15]$. In addition to respiratory system, some pathologies evolve in cardiovascular system and they are resulted from both direct cardiotoxic effect of aromatic and oxygenated hydrocarbons, and mediated changes in autonomic nervous system functioning which are caused by external respiration disorders appearing under adverse influence of anthropogenic chemical factors $[4,9,13,14]$. It is shown that increase in suspended solids concentration in the atmosphere leads to higher thrombus formation risk and vascular tone lability $[4,13,14]$. Besides, long exposure to benzene, phenol, and formaldehyde causes tissue metabolism processes disorders, which can further lead to chronic intoxication [13, 14, 15]. As a result children with bronchial obstruction suffer from hypoxic vasoconstriction leading to higher resistance of pulmonary vessels and higher pressure in pulmonary tissues with further threat of pulmonary hypertension $[2,3,10$, $11]$.

But some issues of morphofunctional changes

(C) Maklakova O.A., Ustinova O.Yu., Belyaeva E.S., Sherbakov A.A., 2016

Ustinova Olga Yurjevna - Doctor of Medical Science, Professor, Deputy Director for Healthcare Services of FBSI (e-mail: ustinova@fcrisk.ru; tel.: + 7 (342) 236-32-64)

Maklakova Olga Anatoljevna - Candidate of Medical Science, Head of Outpatient Department (e-mail: olga mcl@ fcrisk.ru; tel.: + 7 (342) 237-27-92)

Belyaeva Ekaterina Sergeevna - Radiology Physician (e-mail: olga_mcl@ fcrisk.ru; tel.: + 7 (342) 237-27-92).

Shherbakov Aleksandr Alekseevich - Functional Diagnostics Physician (e-mail: olga_mcl@ @fcrisk.ru; tel.: + 7 (342) 237-27-9) 
in cardiac muscle in children suffering from chronic respiratory diseases caused by inhalant effect of adverse environmental factors still remain uncovered.

The purpose of this study was to reveal features of cardiac disorders in children suffering from respiratory diseases associated with adverse effect of inhalant environmental factors (suspended solids, benzene, phenol and formaldehyde).

Data and methods. To reveal features of cardiac disorders in children suffering from chronic respiratory diseases caused by exposure to suspended solids, benzene, phenol and formaldehyde, researchers from FBSI «Federal Scientific Center for Medical and Preventive Health Risk Management Technologies» conducted medical and social interviewing, as well as profound clinical, functional, instrumental, and laboratory studies. Focus group consisted of 43 children suffering from bronchial asthma and recurrent bronchitis in remission; children were aged 6-13 (average age $9.8 \pm 0.53$ years; $47.6 \%$ boys and $52.4 \%$ girls), living in various areas of Perm region where air quality was poor as per sanitary and chemical indicators. According to systematic field observations accomplished by FBHO "Perm Regional Hygiene and Epidemiology Center" in 2013-2014 as a part of social-hygienic monitoring, children lived in the environment in which suspended solids concentration was 1.8-2.2 times higher than MPC, formaldehyde concentration was $1.1 \mathrm{MPC}$, and as for benzene, toluene and phenol, their concentrations were lower than 1.0 MPC. Comparative group consisted of 39 children (average age $9.3 \pm 0.55$ years; $53.5 \%$ boys and $46.5 \%$ girls) suffering from bronchial asthma and recurrent bronchitis in remission and living in conditions of sanitary and hygienic well-being. The groups were comparable in the context of gender, age and social criteria.

To evaluate respiratory system state we used Schiller SP-10 computer spirograph (produced by "Ecomed+" LLC, Russia, in 1999) to conduct spirography with lung vital capacity measuring and test with forced expiration; we also used equipment produced by Erich Jaeger company (Germany) to conduct impulse oscillometry. We studied electophysiological function of cardiac muscle via making electrocardiogram with the use of Schiller AT-10plus; we examined the state of various sections of autonomic nervous system with the use of "Polyspectr" cardiorhythmographic program according to standard procedures. To evaluate contractive heart function and intracardiac hemodynamics with determining basic parameters of bloodstream in heart chambers and valvate system function, we carried out heart ultrasound examination with tissue dopplerography using Vivid E9 expert class device (produced by GE Vingmed Ultrasoung AS, Norway) equipped with sector phase sensor $(2.0-3.8 \mathrm{MHz})$.

Chemical and analytical examination included determining aliphatic aldehydes (formaldehyde) in children's blood using highly efficient liquid chromatography technique according to 4.1.2111-06 Guidelines; aromatic hydrocarbons (benzene, toluene) and phenol were detected with the use of gas chromatography according to 4.1.765-99 Guidelines and 4.1.2108-06 Guidelines.

We analyzed all the obtained data with the use of statistic techniques (Statistica 7.0) as well as with the use of specially designed programs compatible with MS-Office applications. Numerical value validity was estimated according to Fischer and Student's tests; we estimated dependencies between characteristics according to calculation of odds relation index (OR) and its confidence interval (DI). $O R \geq 1$ was defined as a relation occurrence criterion [12].

Results and discussion. The results of chemical and analytical examination showed benzene $\left(0.013 \pm 0.0024 \mathrm{mg} / \mathrm{dm}^{3}\right)$ and toluene $\left(0.025 \pm 0.0047 \mathrm{mg} / \mathrm{dm}^{3}\right)$ content in children's blood in focus group; children in comparative group didn't have such substances in their blood $(p=0.001)$ (Table 1). Phenol concentration in blood of focus group children was authentically 3.2 times higher than that in blood of children in comparative group $(0.013 \pm 0.005$ and $0.0041 \pm 0.004$ $\mathrm{mg} / \mathrm{dm}^{3}$ correspondingly, $p=0.01$ ). Formaldehyde concentration in blood was detected at $0.0057 \pm 0.0016 \mathrm{mg} / \mathrm{dm}^{3}$, and it was statistically authentically higher than in comparative group $\left(0.0025 \pm 0.0011 \mathrm{mg} / \mathrm{dm}^{3}, p=0.001\right)$.

Having analyzed medical and social questionnaires we didn't determine any authentic discrepancies between groups in the context of social criteria. Comparative analysis of complaints occurrence frequency showed that parents of focus group children reported vegetative and psycho-emotional disorders authentically more frequently; such complaints included rapid fatigability (46.5 and $23.1 \%$ correspondingly, $p=0.027)$, headaches (37.2 and $17.9 \%$, $p=0.03$ ), weakness (37.2 and $15.4 \%, p=0.02$ ), increased irritability (34.8 and $20.5 \%$, OR $=1.59$, $p=0.07)$ and anxiety $(16.3$ and $7.7 \%, \mathrm{OR}=2,33, p$ $=0.14)$. Besides, $23.3 \%$ children living in areas where air was polluted with anthropogenic chemical substances complained of pains in heart or intermis- 
sions during physical activity and this parameter was 2.2 times higher than in comparative group $(10.3 \%, \mathrm{OR}=2.72, p=0.07)$. Relative risk of vegetative disorders occurrence was 2.9 times higher in focus group $(O R=2.9 ; D I=1.11-7,54 ; p=$ 0.047).

Evaluation of external respiration function showed that during remissions all average group spirogram parameters of examined children, regardless of place of living, corresponded to physiological standards. However, we detected authentic decrease in three-dimensional velocity parameters (MEF50,
MEF 25, MEF 25-75) in medium- and small-size bronchial tubes in focus group against comparative group ( $p=0.001-0$ 002) (table 2).

Impulse oscillometry showed that each forth child exposed to inhalant effects of anthropogenic environmental factors had signs of peripheral respiratory obstruction during remission of chronic respiratory diseases $(23.8 \%$ in focus group and $7.5 \%$ in comparative group, $p=0.028$ ).

Relative risk of peripheral obstruction was 3.84 times higher in focus group $(O R=3.84 ; D I=1.04$ 14.31; $p=0.06)$.

Table 1

Concentration of chemicals in examined children's blood $(M \pm m), \mathrm{mg} / \mathrm{dm}^{3}$

\begin{tabular}{|c|c|c|c|c|}
\hline Parameter & Background level & Focus group & Comparative group & $p^{*}$ \\
\hline Benzene & 0 & $0.013 \pm 0.0024$ & $0.0 \pm 0.0$ & 0.001 \\
\hline Toluene & 0 & $0.025 \pm 0.0047$ & $0.0 \pm 0.0$ & 0.001 \\
\hline Phenol & $0.01-0.037$ & $0.013 \pm 0.005$ & $0.0041 \pm 0.004$ & 0.01 \\
\hline Formaldehyde & $0.005-0.0076$ & $0.0057 \pm 0.0016$ & $0.0025 \pm 0.0011$ & 0.001 \\
\hline
\end{tabular}

NB $: p^{*}$ - validity of discrepancy between focus group and comparative group

Average spirogram parameters of examined children $(M \pm m), \%$

\begin{tabular}{|c|c|c|c|}
\hline Parameters & Focus group & Comparative group & $p^{*}$ \\
\hline SVC & $95.46 \pm 13.22$ & $11836 \pm 13.7$ & 0.012 \\
\hline FVC & $97.74 \pm 3.88$ & $94.65 \pm 3.41$ & 0.12 \\
\hline FEV1 & $93.20 \pm 3.2$ & $88.31 \pm 4.85$ & 0.15 \\
\hline PEF & $93.24 \pm 4.29$ & $93.59 \pm 5.58$ & 0.92 \\
\hline MEF50 & $87.58 \pm 5.35$ & $105.02 \pm 8.57$ & 0.001 \\
\hline MEF25 & $80.14 \pm 8.66$ & $102.56 \pm 5.45$ & 0.002 \\
\hline
\end{tabular}

NB : $p^{*}$ - validity of discrepancy between focus group and comparative group

Heart functional study results showed that all examined children had physiological parameters of electrocardiogram temporal indexes ( $\mathrm{P}$ wave, $\mathrm{PQ}$ interval, QRS complex, Q-T interval) within the age norm range and there were no authentic discrepancies between groups. However, $17.2 \%$ children had heart electric axis deviation to the right, and it was detected 3.4 times more frequently in focus group than in comparative group $(5.1 \%, p=$ 0.05).

Research of elecrophysiological processes in cardiac muscle carried out for children living on examined territories allowed us to determine the fact that more than a half of children in both groups $(60.9 \%$ in focus group and $56.4 \%$ in comparative group, $\mathrm{p}=0.65$ ) suffered from disorders of excitability, conduction and automatism processes in the form of sinus arrhythmia and bradycardia ( $40.6 \%$ in focus group against $48.7 \%$ in comparative

group, $p=0.42$ ). We detected sinus tachycardia in $15.6 \%$ children in focus group and it was authentically 3.1 times more frequent than in comparative group $(5.1 \%, p=0.001)$. Changes in cardiac muscle conduction processes in the form of incomplete His' right bundle branch block and intraventricular conduction disorders were detected 2.1 times more frequently in focus group $(21.9 \%$ against $10.3 \%$ in comparative group, $p=0.07)$. In general, relative risk of cardiac muscle excitability and conductivity disorders was 2.4 times higher for children from focus group than for children from comparative group $(O R=2.41 ; D I=$ $0.95-6.11 ; p=0.1)$.

As we accomplished comparative estimation of autonomic nervous system functional state in examined children with the use of cardiointervalography we determined that eytony was the 
prevailing type of baseline autonomic tone for children in focus group (36.8\%), sympathico-tonic and vagotonic types were detected with similar frequency $(31.6 \%)$; as for comparative group, vagotony was the prevailing type in it $(40.0 \%)$, and sympathicotony was detected 1.4 times less frequently $(23.3 \%)$, than in focus group $(31.6 \%, p=$ $0.45)$.

Spectral analysis of autonomic rhythm control determined decrease in quantity of high frequency waves (HF \%) representing parasympathetic division activity of autonomic nervous system in children living in unfavorable environmental conditions. At the same time we saw rise in quantity of very low frequency waves (VLF \%), which was the evidence of increased central regulatory effects (neurohumoral and metabolic level) on heart performance. As for comparative group, parasympathetic type of cardiac rhythm autonomic nervous control was prevailing in it (HF \% and LF \%) (table 3).

Autonomic reactivity estimation according to wedge orthostatic test showed that children in both groups mostly had hypersympathicotonic type of response $(60.5 \%$ in focus group and $70 \%$ in comparative group; $p=0.42$ ), and it was the evidence of tension in adaptation and compensation mechanisms of homeostasis maintenance with participation of humoral and metabolic control section. Asympathicotonic reactivity characterized by disorders in response of all autonomic cardiac rhythm control sections and adaptation and compensation mechanisms failure was detected only in children being exposed to anthropogenic chemical factors $(5.3 \%, p=0.42)$. Spectral analysis parameters in orthostatic test were the evidence that cardiac rhythm control in children from focus group was due to greater influence of autonomic nervous system sympathetic division (LF2) and humoral and metabolic mechanisms (VLF2) with simultaneous decrease in vagus activity (HF2), while in comparative group we detected activating of central ergotropic and humoral levels of cardiac rhythm control that were 1.2 times authentically higher than in focus group $(p=0.023)$ (table 4).

As per echocardiography data systolic function parameters of both heart ventricles were up to physiological standards in both groups. We noticed that systolic pressure in pulmonary artery in children from focus group was higher than in comparative group $(9.78 \pm 1.09$ and $8.35 \pm 1.07 \mathrm{~mm} \mathrm{Hg}$ correspondingly, $p=0.05$ ), and it was the evidence of increased load in pulmonary circulation.

Diastolic function parameters for left ventricle were within normal range in both groups and we found no authentic discrepancies between them (table 5). We detected greater maximum speed of early diastolic filling of right ventricle in focus group than in comparative group $(0.56 \pm 0.036$ and $0.52 \pm 0.03 \mathrm{~m} / \mathrm{sec}$ correspondingly, $p=0.08$ ). E/A index (ratio of diastolic filling and atrial systole speeds) was authentically higher in focus group

Spectral analysis parameters of autonomic cardiac control in examined children

$(M \pm m), \%$

\begin{tabular}{|c|c|c|c|}
\hline Parameter & Focus group & Comparative group & $p^{*}$ \\
\hline HF & $41.12 \pm 5.4$ & $48.64 \pm 5.85$ & 0.063 \\
\hline LF & $28.82 \pm 3.05$ & $29.21 \pm 4.23$ & 0.88 \\
\hline VLF & $30.05 \pm 4.29$ & $22.14 \pm 4.37$ & 0.012 \\
\hline
\end{tabular}

$\mathrm{NB}: p^{*}-$ validity of discrepancy between focus group and comparative group.

Spectral analysis parameters of autonomic cardiac control in examined children

according to orthostatic test $(M \pm m), \%$

\begin{tabular}{|c|c|c|c|}
\hline Parameter & Focus group & Comparative group & $p^{*}$ \\
\hline HF2 & $13.93 \pm 2.61$ & $14.23 \pm 2.4$ & 0.87 \\
\hline LF2 & $42.74 \pm 3.25$ & $37.09 \pm 4.42$ & 0.043 \\
\hline VLF2 & $41.46 \pm 4.39$ & $48.67 \pm 4.29$ & 0.023 \\
\hline
\end{tabular}

NB : $p^{*}$ - validity of discrepancy between focus group and comparative group.

Parameters of heart tissue dopplerography in examined children $(M \pm m)$ 


\begin{tabular}{|c|c|c|c|}
\hline Parameter & Focus group & Comparative group & $p^{*}$ \\
\hline Ем, m/sec & $0.95 \pm 0.045$ & $0.94 \pm 0.052$ & 0.76 \\
\hline Ам, m/sec & $0.46 \pm 0.041$ & $0.50 \pm 0.049$ & 0.20 \\
\hline Ем/Ам, st.units & $2.16 \pm 0.22$ & $1.95 \pm 0.19$ & 0.14 \\
\hline Етр, m/sec & $0.56 \pm 0.036$ & $0.52 \pm 0.03$ & 0.08 \\
\hline Атр, m/sec & $0.35 \pm 0.031$ & $0.37 \pm 0.035$ & 0.38 \\
\hline Етр/Aтр, st.units & $1.68 \pm 0.22$ & $1.42 \pm 0.096$ & 0.031 \\
\hline
\end{tabular}

NB : $p^{*}$ - validity of discrepancy between focus group and comparative group.

(1.68 \pm 0.22 standard units in focus group against $1.42 \pm 0.096$ standard units in comparative group, $p=0.031$ ), and it proved occurrence of disorders in relaxation of right ventricle cardiac muscle.

Besides, $17.9 \%$ of children in focus group had transient diastolic dysfunction of right ventricle which was not detected in comparative group ( $p=$ 0.046). Relative risk of disorders in right ventricle cardiac muscle functioning was 6.0 times higher in focus group than in comparative group $(O R=6.0$; $D I=1.13-31.94 ; p=0.05$ ).

Conclusions. Children suffering from chronic respiratory diseases associated with exposure to inhalant chemical factors during remission can have signs of peripheral bronchial obstruction and functional disorders in heart performance.
Changes in autonomic control of heart rhythm manifest themselves in pains in heart or intermissions during physical activity, sinus bradytachycardy, eytonic and/or sympathicotonic baseline autonomic tone caused by activation of central control neurohumoral and metabolic levels, as well as hypersympathicotonic / asympathicotonic autonomic reactivity being the evidence of tension in adaptation and compensatory mechanisms of homeostasis maintenance. Disorders in cardiac muscle functional state are characterized by occurrence of transient diastolic dysfunction of right ventricle and increased systolic pressure in pulmonary artery. The data we obtained allow us to state that under adverse effects of anthropogenic chemical factors children suffering from chronic respiratory diseases run the risk of autonomic dysfunctions of cardiac type.

\section{References}

1. Zaitseva N.V., Ustinova O.Ju., Aminova A.I. Hygienic aspects of health disorders in children exposed to chemical environmental factors. Perm': Knizhnyj format, 2011, 489 p. (in Russian).

2. Ivanov S.N., Ogorodova L.M., Starovojtova E.A. Clinico-functional estimation of cardiorespiratory system in children with bronchial asthma. Bjulleten', issue 24, 2007, pp. 47-51. (in Russian).

3. Kadymov N.A. Clinical and ultrasound characteristics of the cardiovascular system in bronchial asthma in children: Abstract Dis. ... Cand. of Medicine. Moscow, 2009, 126 p. (in Russian).

4. Kucenko S.A. Basics of Toxicology. St. Petersburg: Foliant, 2002, 570 p. (in Russian).

5. Agapitov L.I., Belozerov Ju.M., Mizernickij Ju.L., Cyplenkova S.Je. Pulmonary hemodynamics and diastolic function of right ventricle at isometric exercises in children with chronic bronchopulmonary pathology. Bjulleten' sibirskoj mediciny, 2011, no. 3, pp. 105-110. (in Russian).

6. Nuriahmetova A.Zh., Fajzullina R.M. Clinical and anamnestic characteristics in children with recurrent and chronic respiratory diseases in industrial area. Medicinskij vestnik Bashkortostana, 2013, no. 3, pp. 67-71. (in Russian).

7. Sick rate of the child population in (age of 0-14 years) in 2013: Statistical data. Departament monitoringa, analiza i strategicheskogo razvitija zdravoohranenija Ministerstva zdravoohranenija Rossijskoj Federacii, Moscow, 2014, part 4, 144 p. (in Russian).

8. On the state of sanitary and epidemiological welfare of the population in the Russian Federation in 2013: State Report]. Federal'naja sluzhba po nadzoru $v$ sfere zashhity prav potrebitelej i blagopoluchija cheloveka, Moscow, 2014, 191 p. (in Russian).

9. Guidelines for assessing health risk in the population exposed to the chemicals polluting the environment R.2.1.10.1920-04. Moscow: Federal'nyj centr Gossanjepidnadzora Minzdrava Rossii, 2004, 143 p. (in Russian). 
10. Senatorova A.S., Logvinova O.L., Bojchenko A.D., Galdina I.M. Status of left ventricular diastolic function in children with bronchopulmonary dysplasia. Mezhdunarodnyj zhurnal pediatrii, akusherstva $i$ ginekologii, 2013, Vol. 4, no. 2, pp. 28-33. (in Russian).

11. Fishman I.V., Morockaja M.E.. Roshhevskaja I.M. Morphological and functional features of heart of children living in the north and suffering from bronchial asthma. Jekologija cheloveka, 2008, no. 12, pp. 12-15. (in Russian).

12. Fletcher R., Fletcher S., Vagner Je. Clinical epidemiology. Basics of evidence-based medicine. Moscow.: Media Sfera, 1998, 352 p. (in Russian).

13. Toxicological profile for benzene, US, 2007; U.S. department of health and human services Public Health Service Agency for Toxic Substances and Disease Registry, OEHHA, 2007, 357 p.

14. Toxicological profile for formaldehyde, US, 1999; U.S. department of health and human services Public Health Service Agency for Toxic Substances and Disease Registry, OEHHA, 1999, 468 p.

15. Toxicological profile for phenol, US, 2008; U.S. department of health and human services Public Health Service Agency for Toxic Substances and Disease Registry, OEHHA, 2008, 269 p. 